\title{
Long-term effects of management systems on crop yield and soil physical properties of semi-arid tropics of Vertisols
}

\author{
Prabhakar Pathak ${ }^{*}$, Suhas P. Wani, Raghavendra Rao Sudi \\ International Crops Research Institute for the Semi-Arid Tropics (ICRISAT), Andhra Pradesh, India; \\ *Corresponding Author: p.pathak@,cgiar.org
}

Received 8 September 2011; revised 17 October 2011; accepted 26 October 2011.

\begin{abstract}
Long-term experiments can be used to assess management induced changes in soil properties and sustainability of the management system in terms of the productivity. Such data are scanty, especially in the semi-arid tropics (SAT) region. A long-term experiment established in 1976 at ICRISAT in India on Vertisols with two management treatments; improved management (IM), comprising semi-permanent broadbed and furrow (BBF) landform with minimum tillage and improved cropping practices; and traditional management (TM) system comprising keeping the land fallow during the rainy season and sowing on flat landform during post-rainy season with traditional cropping practices, was sampled after 24 and 34 years for soil physical and hydrological properties. Results showed that both in short- and long-term the management systems had profound effect on crop yields. Also in the long-term IM and TM management systems had significant effect on several soil physical and hydrological properties. Throughout the soil profile IM systems had significantly lower bulk density, significantly higher porosity, substantially lower penetration resistance both at $5 \mathrm{~cm}(1$ and $8 \mathrm{MPa})$ and $15 \mathrm{~cm}$ depths (8 and $15 \mathrm{MPa}$ ), significantly higher infiltration and sorptivity and significantly larger mean weight diameter of $4.3 \mathrm{~mm}$ compared to $2.8 \mathrm{~mm}$ for soils under TM. However, management systems had no significant effect on moisture holding capacities both at 0.033 and $1.5 \mathrm{MPa}$. Significant differences between the improved and traditional systems were observed in the size and pattern of soil surface cracks. Over the longterm, the improved management systems has very favorable effects on soil physical and hy-
\end{abstract}

drological properties and on the soil surface cracking and its patterns, thereby contributing to higher productivity.

Keywords: Broadbed and Furrow System; Minimum Tillage; Long-Term Experiment; Sustainability

\section{INTRODUCTION}

Vertisols are one of the major soil orders found in the semi-arid tropics (SAT). Due to unreliable and variable rainfall, proneness to water logging, difficulty in tillage operations due to sticky nature of wet soils and risk aversion of farmers in many rainfall zones in Indian SAT, Vertisols are kept fallow in the rainy season [1]

Crops are grown only in post-rainy season on the stored moisture in the soil profile. The implications of the rainy season fallow system are serious both in terms of the overall productivity and with regard to the frequent occurrence of large quantities of runoff and soil loss [2]. The lack of vegetative cover during most of the rainy season exposes the surface soil to the impact of high intensity storms, causing severe soil erosion [3]. The traditional crop production system often results in low crop yields, high runoff and soil loss, reduced groundwater recharge and frequent flooding of the downstream lands [4].

To develop an improved crop production system that enables crops to be grown in both the rainy and the postrainy seasons, and improves agricultural productivity and rainwater use efficiency on a sustainable basis, a long-term experiment was initiated on the Vertisols at ICRISAT research station, Patancheru in 1976. It was envisaged that substantial gains in total food production can be attained if the present post-rainy season cropping can be replaced by systems that permits growing of two crops in the rainy and post-rainy seasons. However to enable cropping during the rainy season, an appropriate 
tillage and land and water management system that reduces the problem of water logging and allow timely tillage operations was essential. The semi-permanent broadbed and furrow system with minimum tillage (BBF/MT) was found appropriate for the in-situ soil and water conservation and reducing water logging problem in these Vertisols [5]. Long-term experiments with BBF/MT along with other improved cropping practices, have clearly demonstrated that advantages and profitability of this improved system [6,7]. There was also clear evidence of increased soil organic $\mathrm{C}$, total $\mathrm{N}$ and $\mathrm{P}$, available $\mathrm{N}, \mathrm{P}$ and $\mathrm{K}$, and microbial biomass $\mathrm{C}$ and $\mathrm{N}$ in the soil under improved management system [8].

The objective of this study was to assess the long-term effects of the improved management system (BBF/MT with improved cropping practices) and traditional management system (flat cultivation with traditional tillage and cropping practices) system on crop yields, physical and hydrological properties of the Vertisols. The effects of management systems on soil surface cracking and its pattern in the Vertisols were also studied. The implications of these changes in physical and hydrological properties and cracking pattern for tillage, soil and water management and crop productivity are discussed.

\section{MATERIALS AND METHODS}

\subsection{Experimental Site}

The experiments were conducted in two adjacent small Vertisol watersheds [3.5 ha Black soil Watershed 1 (BW1) and 3.2 ha Black soil Watershed 4C (BW4C)] to evaluate the long-term effect of tillage and crop manage- ment systems on crop productivity and soil quality at ICRISAT Center, near Hyderabad, Patancheru, India $\left(17^{\circ} 36^{\prime} \mathrm{N}\right.$, $78^{\circ} 16^{\prime} \mathrm{E}$, $545 \mathrm{~m}$ altitude) (Figure 1). Two management systems (improved and traditional) were studied under long-term experiments initiated in 1976. The average slope of the experimental watersheds is about $2.0 \%$.

The mean annual rainfall at the experimental area is about $800 \mathrm{~mm}$; the average minimum temperature is $17^{\circ} \mathrm{C}$ and maximum temperature is $32^{\circ} \mathrm{C}$. Rainfall is variable temporally and during the experimental period (1976-2009) annual rainfall ranged from 518 to 1194 $\mathrm{mm}$. Spells of excess moisture and drought during the crop-growing period are common. About $80 \%$ of annual rainfall occurs between June and September and is known as the monsoon or kharif, in which rainfed crops are grown. The post-rainy winter season from October to January, also known as rabi, is dry and cool and days are short.

\subsection{Soils}

The soils at the experimental site belong to the very fine, clayey, montmorillonitic, calcareous hyper thermic family of typic pallusterts and are classified as "Vertisols" Kasireddipalli series [4]. These Vertisols are high in montmorillinitic clay (40\% to $64 \%)$ and undergo pronounced shrinkage during drying, resulting in large cracks that close only after prolonged rewetting. These soils become hard when dry and sticky when wet. Thus, tillage operations must coincide with the specific range of soil water contents at which the soil is trafficable. Drainage during wet periods in the rainy season can be a serious problem.

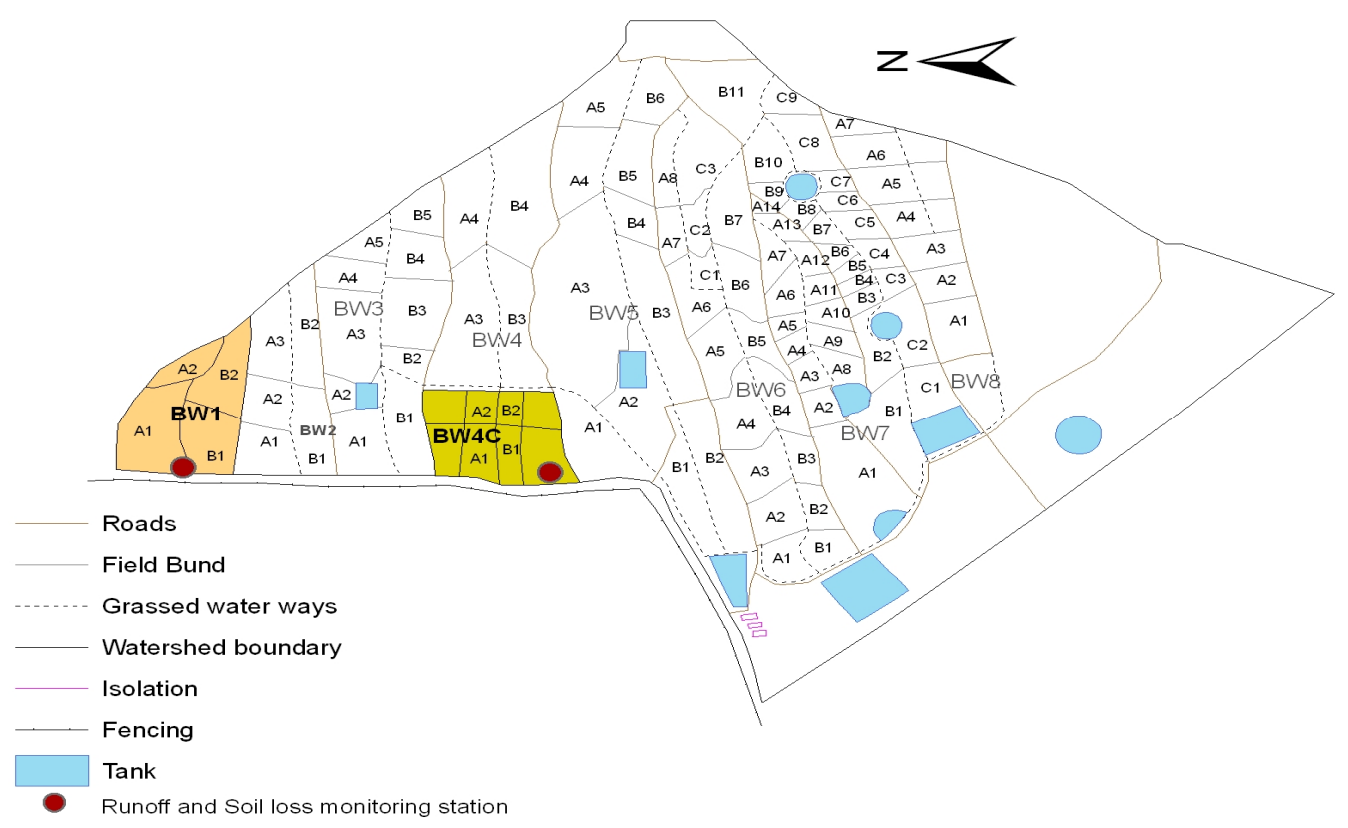

Figure 1. Experimental watersheds (BW1 and BW4C) at the ICRISAT research station, Patancheru, India. 


\subsection{Treatment Details}

The details of two management systems are given below:

\subsubsection{Improved Management System (BW1 Watershed)}

This system includes a semi-permanent broadbed and furrow system with minimum tillage (BBF/MT) only in the beds along with improved cropping practices [4]. The beds are $1.0 \mathrm{~m}$ wide with $0.5 \mathrm{~m}$ furrows prepared at $0.6 \%$ gradient using a bullock drawn bed-maker mounted on a tropicultor. Field traffic was confined to the furrows. Excess rainfall drains along the furrows and is discharges into grassed waterways [9]. Improved agronomic practices, viz. use of high-yielding varieties, dry sowing ahead of the rainy season, nutrient management, integrated pest management and other improved practices, were followed [8]. In view of the difficult workability of Vertisols both in the very dry and very wet conditions, primary tillage was done immediately after the harvest of post-rainy season crop. Final land preparation was initiated immediately following initial rains so that the system is again ready for pre-monsoon sowing of the next year's crop.

\subsubsection{Traditional Management System (BW4C Watershed)}

In this system the land was left as cultivated bare fallow during the rainy season and sorghum and chickpea were grown as sole crop in the post-rainy season [10]. Sowing was done with a local seed drill on a flat surface when seedbed moisture was adequate. No chemical fertilizers were applied to the crop, but $10 \mathrm{t} \cdot \mathrm{ha}^{-1}$ of farmyard manure (FYM) was broadcasted each alternate year before land preparation (farmers practice). The land was ploughed every two years; harrowing was done with a blade harrow to control weeds.

\subsection{Soil and Crop Sampling}

After 24 (April 1999) and 34 years (April 2009) of experimental cycles, both watersheds (BW1 and BW4C) were sampled for detailed physical and hydrological properties of two profile pits were dug in each watershed and three replicated samples were collected for texture, bulk density, and porosity measurements from each pit up to $1.2 \mathrm{~m}$ depth at increments of $15 \mathrm{~cm}$ [11]. The soil samples from both the watersheds at 2 layers $(0-15$ and $15-30 \mathrm{~cm}$ ) were collected for aggregate analysis by wet sieving method for mean weight diameter of soil aggregates. Infiltration measurements were done at four locations each at surface on bed and furrow of BW1 and four locations in BW4C watershed [12]. Penetration resistance readings were made in both the improved (80 observations) and traditional (20 observations) treatments depending up on the variations in each of the watersheds. The samples from BW1 were collected from the centre of beds and in furrows. Table 1 gives the details of number of samples collected for various physical properties of soil.

For estimating the crop yields, samples from 24 randomly selected spots (each $12 \mathrm{~m}^{2}$ area) were collected from the each treatment. After taking the fresh weight of grain and biomass, the samples were kept in drier for obtaining dry weights.

\subsection{Statistical Analysis}

Soil physical and hydrological data obtained from watersheds $\mathrm{BW} 1$ and $\mathrm{BW} 4 \mathrm{C}$ were analyzed using the analysis of variance method in GENSTAT 5 with management systems as main treatments and soil depths as sub-treatments. The significant differences between main and sub-treatments and interaction effects were studied by comparing the " $F$ " test of significance and standard error of means.

Table 1. Details of samples collected for soil physical properties determination.

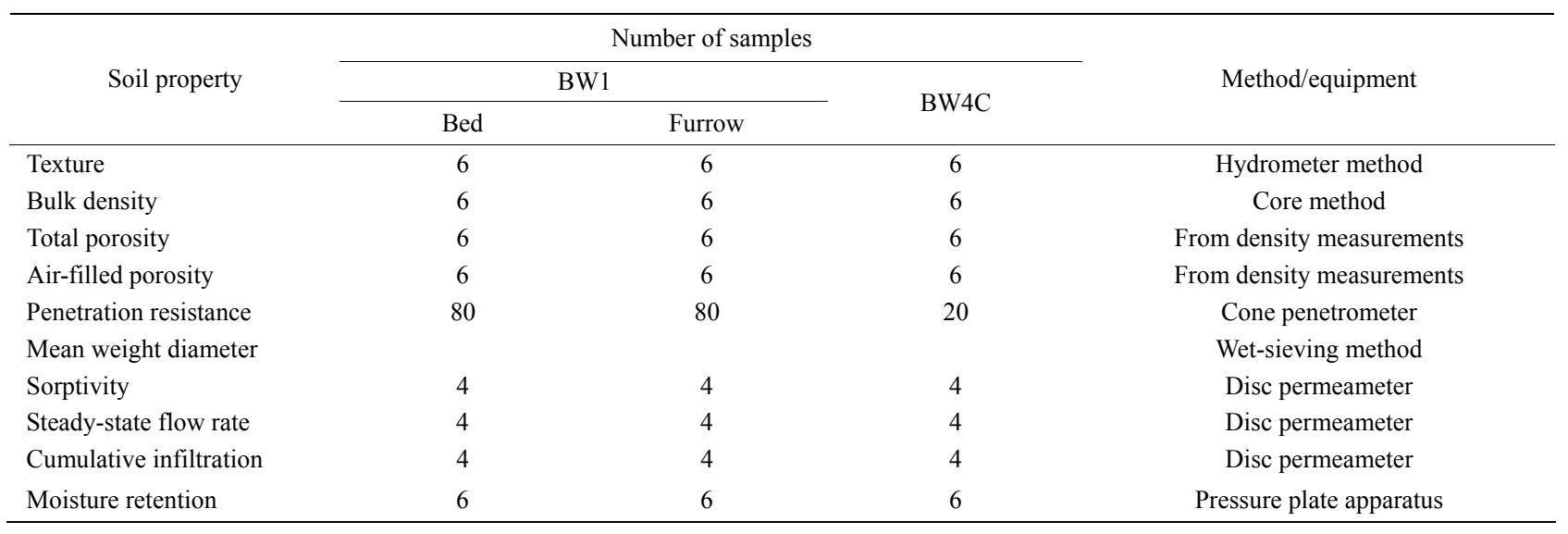




\section{RESULTS AND DISCUSSION}

\subsection{Crop Productivity}

The crop yields were higher in the improved system (semi-permanent broadbed and furrow with minimum tillage along with improved cropping systems and management) than in the traditional system (monsoon fallow with flat landform with traditional cropping practices). In the improved system the sorghum and pigeonpea together recorded an average grain yield of $5.3 \mathrm{t} \cdot \mathrm{ha}^{-1} \cdot \mathrm{yr}^{-1}$ compared with the $1.2 \mathrm{t} \cdot \mathrm{ha}^{-1} \cdot \mathrm{yr}^{-1}$ in traditional system (Figure 2). The annual gain in grain yield in the improved system was $82 \mathrm{~kg} \cdot \mathrm{ha}^{-1} \cdot \mathrm{yr}^{-1}$ compared with 23 $\mathrm{kg} \cdot \mathrm{ha}^{-1} \cdot \mathrm{yr}^{-1}$ in the traditional system. The initial big difference in crop yields between the two systems was mainly due to two crops per year in improved system vs one crop per year in traditional system. Also the improved system had improved varieties and cropping system along with other improved management compared to traditional variety and traditional management practices in traditional system. Significant contribution had also come from the improved BBF landform and tillage system, which facilitated the cropping during the rainy season by improving surface drainage and reducing water logging problem. The improved system of $\mathrm{BBF}$ landform reduced seasonal runoff from $174 \mathrm{~mm}$ measured within the traditional system to $99 \mathrm{~mm}$, improving soil water content and reducing annual soil losses from $6.46 \mathrm{t}^{\mathrm{h} h \mathrm{~h}^{-1}}$ to $1.51 \mathrm{t} \cdot \mathrm{ha}^{-1}$ [3]. However, subsequent annual gain in grain yield must have come from the gradual improved soil health. The small annual gain in crop yield observed in the traditional system can be attributed to the organic fertilizers (FYM) incorporated into the system. However, the large annual gain in the crop yield in the improved system could be attributed to gradual im- provement in soil health (soil physical, chemical and biological properties). The improved system [8] reported the positive changes in the soil chemical and biological properties from the same experiment. The changes in the soil physical and hydrological properties are discussed in the subsequent sections of this paper.

\subsection{Soil Physical Properties}

\subsubsection{Mean Weight Diameter}

Management system had a significant effect on the mean weight diameter of water stable aggregates (Table 2). After 34 years of experimentation, the soils in im- proved management had significantly larger mean weight diameter compared to soils under traditional management. This trend was seen both at $0-15$ and $15-30 \mathrm{~cm}$ soil layers. This may be attributed to relatively more crop residue, minimum tillage in the cropping zone and higher microbial activity in the improved system.

\subsubsection{Penetration Resistance}

The soils under improved management had lower penetration resistance at 5 and $15 \mathrm{~cm}$ depths compared to soils under traditional management (Figure 3). For example, at $5 \mathrm{~cm}$ depth the penetration resistance of soils in the improved system was 1.1 compared to $9.8 \mathrm{MPa}$ in the traditional system. This suggests a progressive improvement in soil tilth occurred in the cropping zone (bed zone) over time. So in the BBF system the tillage operations in the bed zone (cropping zone) became progressively easier, allowing timely tillage operations which is so crucial for SAT Vertisols in view of their difficult workability in the dry and wet conditions. Therefore in the long-term, the semi-permanent BBF system facilitates land preparation during the summer season and dry sowing of the rainy season crop, which are prerequisites for the double cropping in such SAT environments.

\subsubsection{Soil Texture}

A significant difference in texture between improved and traditional management systems was observed only in top $10 \mathrm{~cm}$ soil layer (Table 3). After 24 and 34 years of experimentation the improved system had signifycantly higher clay content $(51 \%$ and $50 \%)$ compared to

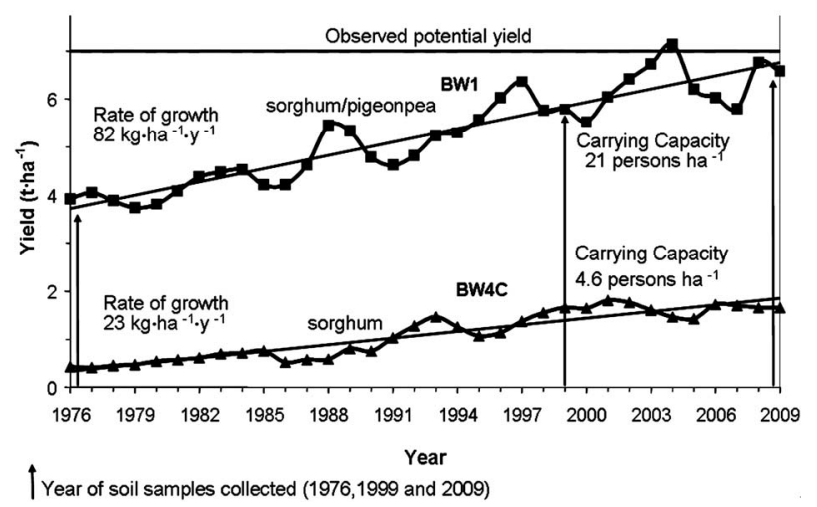

Figure 2. Three-year moving average of sorghum and pigeonpea grain yield under improved (BW1) and traditional (BW4C) management systems in deep Vertisol catchment at ICRISAT, Patancheru, India.

Table 2. Long-term effects of management systems on mean weight diameter $(\mathrm{mm})$ of water stable aggregates.

\begin{tabular}{|c|c|c|c|c|c|c|}
\hline \multirow{2}{*}{$\begin{array}{l}\text { Depth } \\
\text { (cm) }\end{array}$} & \multicolumn{2}{|c|}{ Improved system } & \multirow{2}{*}{ SEM } & \multicolumn{2}{|c|}{ Traditional system } & \multirow{2}{*}{ SEM } \\
\hline & 1976 & 2009 & & 1976 & 2009 & \\
\hline $0-15$ & 3.0 & 4.1 & \pm 0.251 & 2.9 & 2.7 & \pm 0.069 \\
\hline $15-30$ & 3.1 & 4.5 & \pm 0.158 & 3.0 & 2.8 & \pm 0.161 \\
\hline
\end{tabular}


Table 3. Long-term effects of management systems on soil texture $(0-10 \mathrm{~cm})$.

\begin{tabular}{|c|c|c|c|c|c|c|c|c|}
\hline \multirow{2}{*}{ Texture } & \multicolumn{3}{|c|}{ Improved system } & \multirow{2}{*}{ SEM } & \multicolumn{3}{|c|}{ Traditional system } & \multirow{2}{*}{ SEM } \\
\hline & 1976 & 1999 & 2009 & & 1976 & 1999 & 2009 & \\
\hline Clay $(\%)^{* *}$ & 52 & 51 & 50 & \pm 0.675 & 52 & 46 & 45 & \pm 0.985 \\
\hline Silt (\%) & 22 & 21 & 21 & \pm 0.792 & 22 & 22 & 21 & \pm 0.896 \\
\hline Fine sand (\%) & 15 & 15 & 16 & \pm 0.981 & 14 & 15 & 16 & \pm 1.089 \\
\hline Coarse sand $(\%)^{* *}$ & 12 & 13 & 13 & \pm 0.725 & 12 & 17 & 18 & \pm 0.741 \\
\hline Gravel (\%)** & 4 & 5 & 5 & \pm 0.133 & 4 & 11 & 13 & \pm 2.102 \\
\hline
\end{tabular}

traditional management ( $46 \%$ and $45 \%$ ). There was no significant difference in silt and fine sand contents. The coarse materials (coarse sand and gravel) were significantly higher in traditional management. The texture analyses indicates the long-term effect of the differential soil erosion between the improved and traditional management systems, with higher soil erosion in the traditional systems $\left(6.5 \mathrm{t} \cdot \mathrm{ha}^{-1} \cdot \mathrm{yr}^{-1}\right)$ compared with the improved system $\left(1.5 \mathrm{t} \cdot \mathrm{ha}^{-1} \cdot \mathrm{yr}^{-1}\right)$ resulting in greater removal of finer soil particles from the cultivated topsoil layer [3].

\subsubsection{Bulk Density}

At beginning of the experiment, the soil bulk density of different layers in two experimental watersheds was similar (Figure 4). After 24 and 34 years of experiments, the bulk density throughout the soil profile (up to $105 \mathrm{~cm}$ ) was significantly lower with improved management than in traditional management. However, the differences in bulk densities were relatively greater in the top $20 \mathrm{~cm}$ soil layer and the maximum difference in bulk density between the two treatments was recorded in the top 0 $10 \mathrm{~cm}$ soil layer. These data clearly show the advantage of improved management system over the traditional management system in keeping the soil loose which has major implications for tillage (time, and energy requirement), water movement, aeration and root growth. It appears that the large changes in bulk density in the top $0-20 \mathrm{~cm}$ soil layer have occurred mainly because of the different tillage systems, which had been followed in the improved and traditional systems.

\subsubsection{Porosity and Air-Filled Porosity}

The long-term effect of improved and traditional management on total porosity and air-filled porosity are shown in (Figure 5). Both air-filled porosity and total porosity recorded from the improved system were significantly higher compared to values recorded from traditional system. In the improved system the air-filled porosity in top $30 \mathrm{~cm}$ soil layer had improved by $46 \%$ during the first 24 years of experiments (1976-1999). In the traditional management system no significant changes in porosity and air-filled porosity was recorded even after 24 and 34 years of experimentations. These data indicate the effectiveness of the improved management system in improving soil porosity and air-filled porosity, thereby improving the internal profile drainage in the seed and root environment of Vertisols. This has major implications for Vertisols where during rainy season the waterlogging is often a serious problem mainly due to very low saturated hydraulic conductivity and poor internal profile drainage needed.

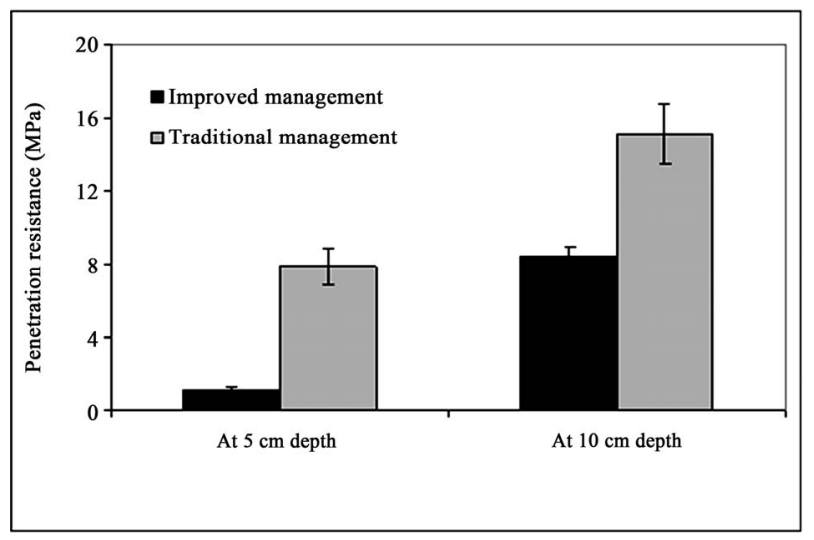

Figure 3. Long-term effects of improved vs. traditional management systems on soil penetration resistance.

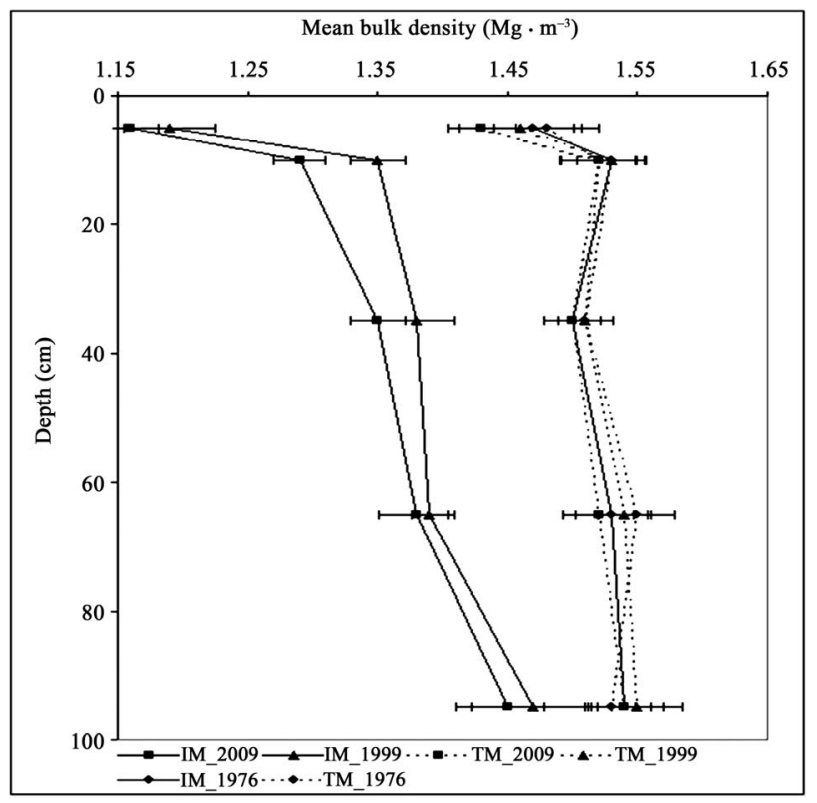

Figure 4. Long-term effects of improved vs. traditional management systems on bulk density of soils. 


\subsection{Hydrological Properties (Moisture Retention, Infiltration and Sorptivity)}

Even after the 24 and 34 years of experimentations, no significant difference in soil moisture retention properties both at 0.033 and $1.5 \mathrm{MPa}$ were recorded in the soil samples from improved and traditional management systems (Table 4).

After 24 years of experimentations, significantly higher initial infiltration rate $\left(347 \mathrm{~mm} \cdot \mathrm{h}^{-1}\right)$ was recorded in improved management system compared to traditional management system $\left(265 \mathrm{~mm} \cdot \mathrm{h}^{-1}\right)$. Similar trend in in-

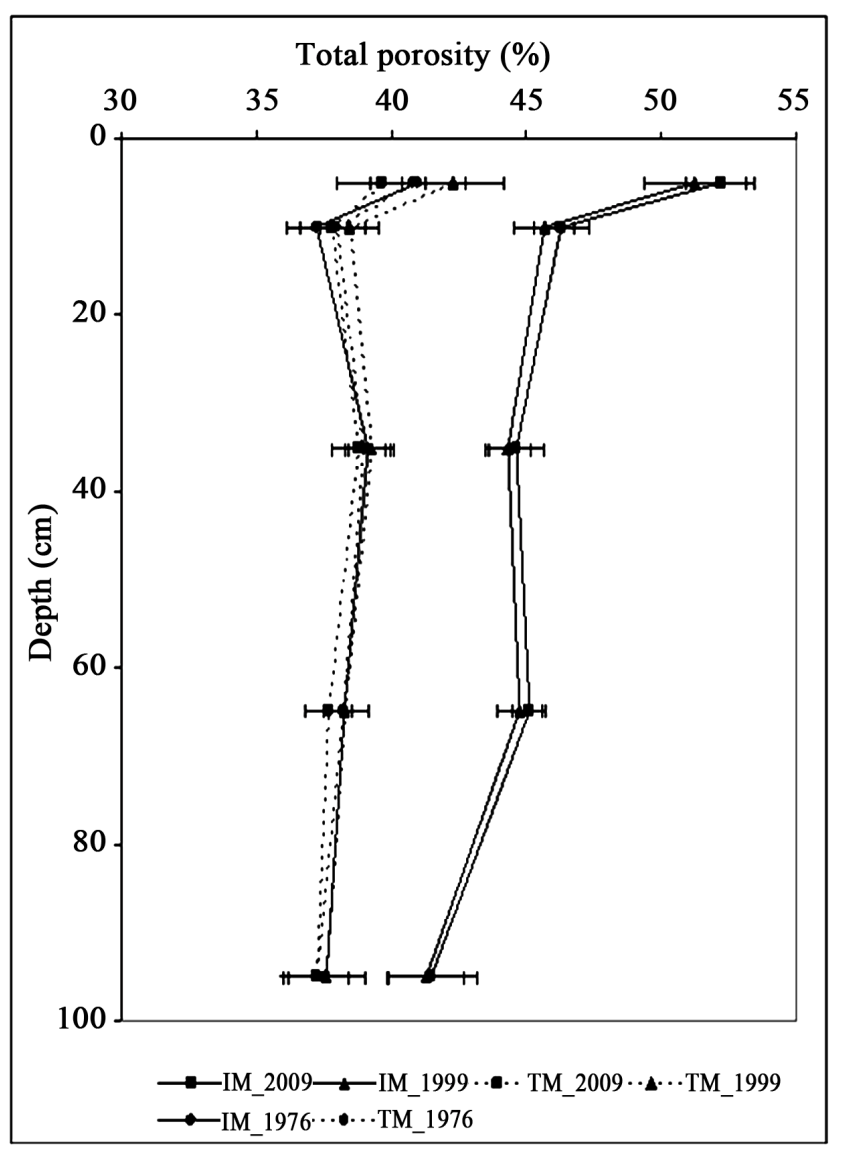

filtration rate was recorded after 34 years of experiments. The sorptivity value was also significantly higher in improved management system $\left(121 \mathrm{~mm} \cdot \mathrm{h}^{-1 / 2}\right)$ than in traditional management system $\left(88 \mathrm{~mm} \cdot \mathrm{h}^{-1 / 2}\right)$. These values indicate the long-term effects of improved and traditional tillage and crop management systems on hydrological properties of soils. These changes in soil properties may have contributed in reduced runoff recorded from the improved management system. On an average (from 1974 to 1993) the improved tillage and crop management system reduced annual runoff from $220 \mathrm{~mm}$ measured from the traditional tillage and crop management system only to $91 \mathrm{~mm}$ [13].

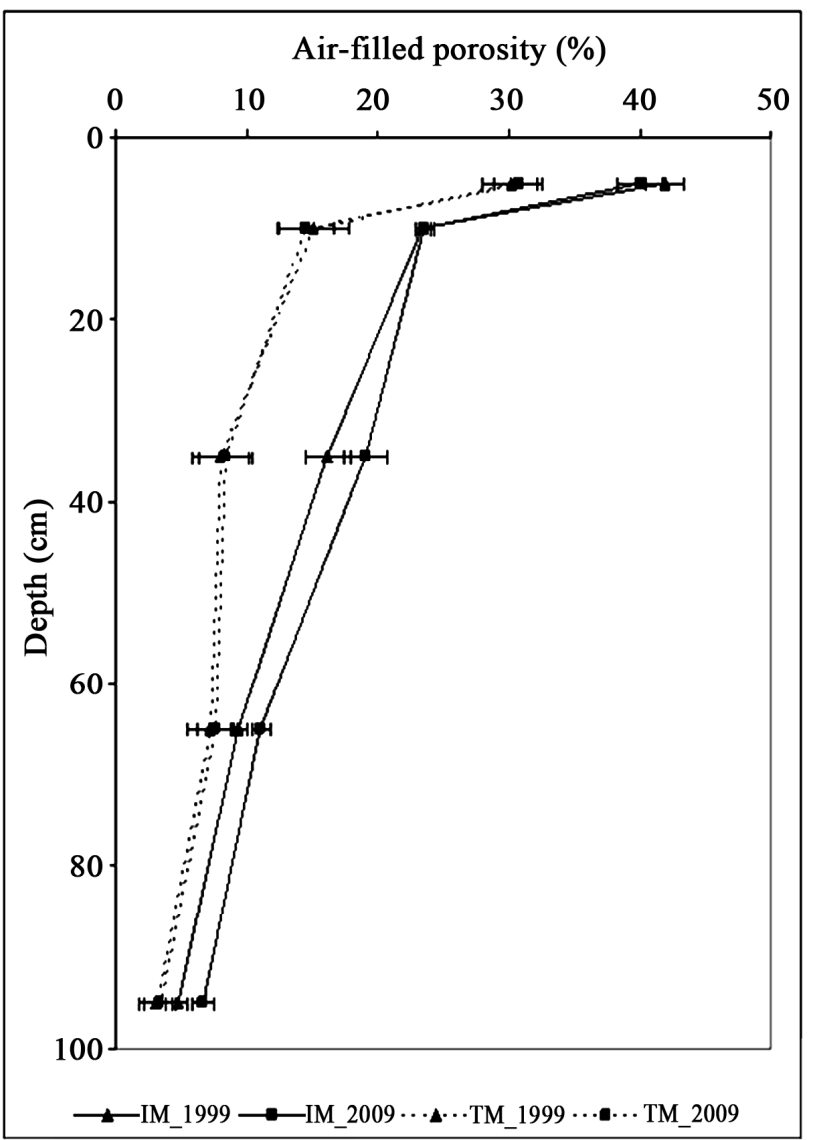

Figure 5. Long-term effects of improved vs. traditional management systems on total and air-filled porosity of soils.

Table 4. Change in the hydrological properties of soils in improved and traditional management system.

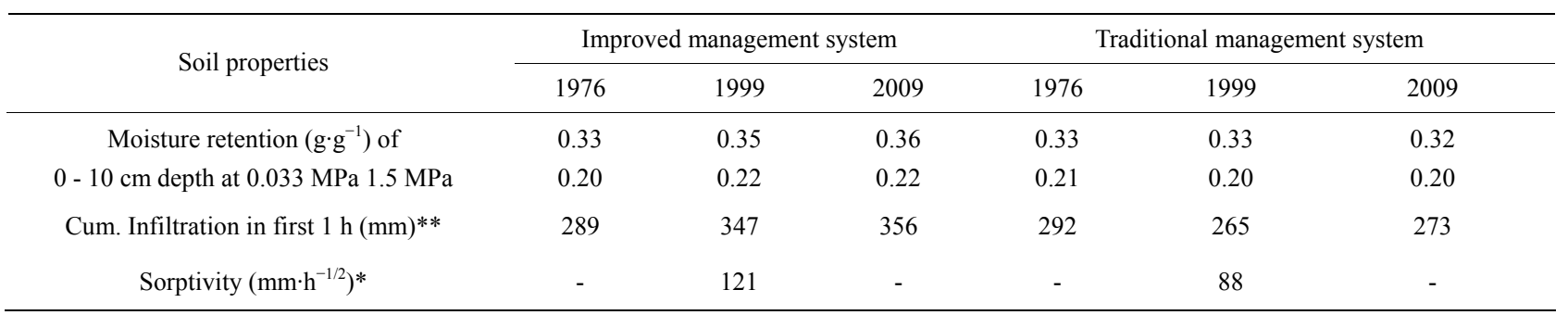

*Significant at 0.05 and **highly significant at $<0.001$ probabilities; -not measured 

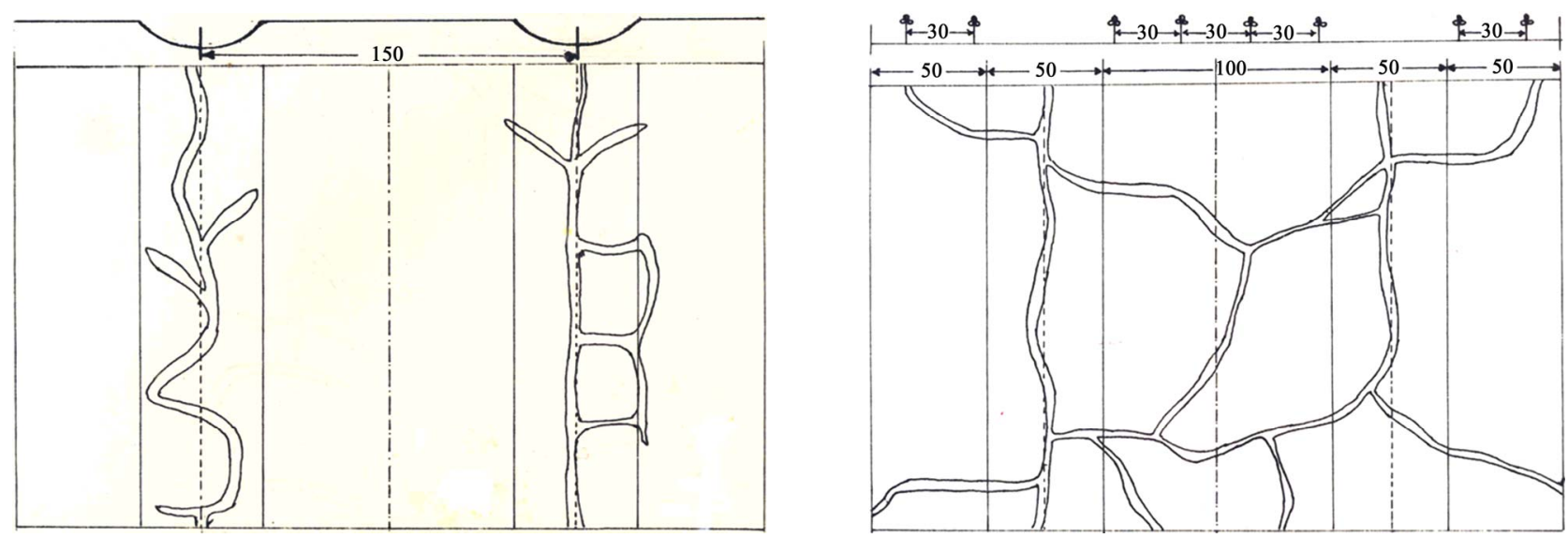

Figure 6. Long-term effects of improved vs. traditional management systems on cracking pattern.

\subsection{Surface Cracks and Its Pattern}

The development of cracks owing to shrinkage is a major structural feature of Vertisols. Big cracks, extending deep into the profile, define major structural features and play an important role in several soil and water processes [14].

Significant differences between the two treatments were observed in the pattern, area and density of cracks. The total length of cracks ( $1.17 \mathrm{vs} 2.1 \mathrm{~m}$ per $\mathrm{m}^{2}$ of land area) and its area ( 0.07 vs $0.16 \mathrm{~m}^{2}$ per $\mathrm{m}^{2}$ of land area) was found significantly lower in the improved management system compared traditional management system (Figure 6). In watershed with improved management (semi-permanent BBF land treatment) most of the cracks were found in the furrows, which serve as traffic zone. The presence of cracks in bed or cropping zone were relatively fewer. Soil compaction due to farm machinery wheel traffic and human trampling induced deeper and wider surface cracks in the furrows, which got developed with further drying into big cracks. Since compaction was restricted to particular traffic zone, most large cracks were located in the furrows only. Within the traditional management system (flat land treatment) cracks were found all over including in the cropping zone (Figure 6).

Cracking patterns could affect germination, seedling establishment, vegetative growth, root development and crop yields $[6,15]$. Although the wider and deeper cracks were found in furrows of semi-permanent BBF in improved management compared to flat land configuration in traditional management, it may not affect the crop growth on $\mathrm{BBF}$ as the cracks were at a distance from the crop zone. Where as, in traditional management the crop growth was affected due to formation of cracks in the crop zone, which were at a closer distance to the crops resulting in an uneven moisture distribution and relatively lower available soil moisture in the root zone.
In the improved system however the presence of large cracks in the furrows could greatly increase the initial infiltration by intercepting the runoff particularly during the early parts of the rainy season. The runoff recorded during the early parts of the rainy season supports this hypothesis [3]. During high rainfall years the Vertisols have severe waterlogging problem mainly due to poor profile internal drainage. Wider and deeper cracks created by compacted zone in improved system could prolong the useful life of cracks as large drainage voids for the soil in the neighboring zone. This mechanism may significantly help in reducing the waterlogging problem in the improved management system.

\section{CONCLUSIONS}

The results indicate that in the long-term, the improved management system (BBF landform along with minimum tillage and appropriate crop management practices) substantially increased the crop yields as well as improved the physical and hydrological properties of SAT Vertisols. The results also indicate that with this improved management system it is possible to achieve the substantially higher crop productivity along with improved soil quality. In the long-term the improved management system resulted in lower bulk density and penetration resistance and higher porosity compared with traditional management system (flat cultivation, monsoon fallow with traditional practices). Similarly, soil hydrological properties (infiltration and sorptivity) were more favorable in improved management system than traditional management system. The improved management system resulted in larger mean weight diameter of soil particles and better soil aggregation and more favorable soil surface cracking and its pattern.

The favorable soil physical and hydrological properties recorded under the improved management system have positive implications for the cultivation and timely 
tillage operations on SAT Vertisols under both dry and wet soil conditions. The timely tillage is one of the major constraints for improved management of Vertisols particularly during the rainy season. The implications of traditional with no crops during rainy season (or monsoon fallow) are serious both in terms of the overall crop productivity and with regard to soil degradation through high runoff and soil loss.

Significantly higher porosity and air-filled porosity recorded under the improved management system indicate the effectiveness of this system in improving the waterlogging problem in SAT Vertisols. The favorable changes in soil physical, hydrological properties and cracking pattern under improved management system must have contributed in increasing and sustaining the crop productivity, which recorded about 5 times higher compared to traditional management system.

\section{ACKNOWLEDGEMENTS}

This paper is based on the long-term experiments at Heritage watersheds ICRISAT Center, Patancheru, India, financial support provided by S. M. Sehgal Foundation for Heritage watersheds is gratefully acknowledged. We acknowledge the help and contribution of all the scientists and staff who have been associated with these experiments. The authors are highly thankful to Dr. Peter Craufurd for his comments and suggestions in improving the manuscript.

\section{REFERENCES}

[1] Michaels, G.H. (1982) The determinants of kharif fallowing on the Vertisol in semi-arid tropical India. Ph.D. Thesis, University of Minnesota, Minneapolis.

[2] Pathak, P., Singh, S. and Sudi, R. (1986) Soil and water management alternatives for increased productivity on SAT Alfisols. Proceedings of the IV International Conference on Soil Conservation, Maracay, 3-9 November 1986, 533-550.

[3] Pathak, P., Sudi, R. and Wani, S.P. (2011) Hydrological behaviour of Alfisols and Vertisols in the semi-arid zone: Implications for soil and water management. Agricultural Water Management Journal (submitted).

[4] El-Swaify, S.A., Pathak, P., Rego, T.J. and Singh, S. (1985) Soil management for optimized productivity under rainfed conditions in the semi-arid tropics. Advances in Soil Science, 1, 1-64. doi:10.1007/978-1-4612-5046-3 1
[5] Pathak, P., Mishra, P.K., Rao, K.V., Wani, S.P. and Sudi, R. (2009) Best options on soil and water conservation. In: Wani, S.P., Venkateswarlu, B. Sahrawat, K.L., Rao, K.V. and Ramakrishna, Y.S., Eds., Best Bet Options for Integrated Watershed Management, Proceedings of the Comprehensive Assessment of Watershed Programs in India, ICRISAT, Pantancheru 502 324, Andhra Pradesh, 75-94.

[6] Srivastava, K.L., Smith, G.D. and Jangawad, L.S. (1990) Zonal surface management for rainfed Vertisols. In: Challenges in Dryland Agriculture-A Global Perspective. Proceedings of the International Conference on Dryland Farming, Amarillo/Bushland, 15-19 August 1988, 584-585.

[7] Virmani, S.M., Pathak, P. and Singh, R. (1991) Soil related constraints in dry land crop production in Vertisols, Alfisols and Entisols of India. Bulletin of Indian Society of Soil Science, 15, 80-95.

[8] Wani, S.P., Pathak, P., Jangawad, L.S., Eshwaran, H. and Singh, P. (2003) Improved management of Vertisols in the semi-arid tropics for increased productivity and soil carbon sequestration. Soil Use and Management, 19, 217-222. doi:10.1111/j.1475-2743.2003.tb00307.x

[9] Kampen, J. (1982) An approach to improved productivity on deep Vertisols. ICRISAT, Andhra Pradesh, ICRISAT Information Bulletin, 11.

[10] Laryea, K.B., Pathak, P. and Klaij, M.C. (1991) Tillage systems and soils in the semi-arid tropics. Soil and Tillage Research, 20, 201-218. doi:10.1016/0167-1987(91)90040-5

[11] Klute, A. (1986) Methods of soil analysis. Part 1: Physical and mineralogical methods. 2nd Edition, American Society of Agronomy and Soil Science Society of America, Madison, USA.

[12] White, I. and Sully, M.J. (1987) CSIRO disc-permeameter: Instruction manual. CSIRO Division of Environmental Mechanics, Canberra.

[13] Pathak, P. and Laryea, K.B. (1995) Soil and water conservation in the Indian SAT: Principles and improved practices. In: Singh, R.P., Ed., Sustainable Development of Dryland Agriculture in India, Scientific Publishers, Jodhpur, 83-94.

[14] Bouma, J. (1984) Using soil morphology to develop measurement methods and simulation technique for water movement in heavy clay soils. In: Bouma, J. and Raats, P.A.C., Eds., Proceedings of ISSS Symposium on Water and Solute Movement in Heavy Clay Soils, ILRI, Wageningen, 27-31 August 1984, 298-310.

[15] Younger, D.R. and Gilmore, J.M. (1978) Studies with pasture grasses on the black cracking clays of the Central Highlands. I. Species evaluation. Tropical Grassland, 12, 152-162. 